\title{
Teknik Konservasi Mataair Berdasarkan Karakteristiknya : Studi Kasus Dusun Sumberwatu dan Dusun Dawangsari, Prambanan, di. Yogyakarta
}

\author{
Akhmad Khahlil Gibran¹, dan Nur Idham Kholid² \\ 1Teknik Geologi, Universitas Jenderal Soedirman; e-mail: akgibran@unsoed.ac.id \\ 2Dinas Lingkungan Hidup Kota Magelang
}

\begin{abstract}
ABSTRAK
Di Dusun sumberwatu dan Dusun Dawangsari terdapat tiga mataair yang dapat digunakan untuk memenuhi kebutuhan air. Tiga mataair tersebut belum mampu memenuhi kebutuhan warga selama musim kemarau. Kulaitas air yang dihasilkan juga belum diuji standar baku mutu air bersih, sehingga dipelukan upaya konservasi untuk meningkatkan kuantitas dan kualiatas agar memenuhi standar baku mutu air bersih. Penelitian ini bertujuan untuk memberikan Teknik konservasi yang tepat berdasarkan karakteristik mataair (tipe, kuantitas, dan kualitas) dan menentukan letak daerah imbuhan. Metode survei, wawancara, dan matematis digunakan untuk mencapai tujuan penelitian. Aspek-aspek yang diolah terdiri atas topografi, kemiringan lereng, kebutuhan air masyarakat, kondisi fisik, kimia, dan biologi air mataair. Dari data aspek-aspek tersebut dianalisis dan diinterpretasikan sehingga mendapatkan teknik konservasi yang tepat. Dari hasil penelitian, diperoleh mataair tersebut terbentuk oleh adanya tenaga gravitasi, dengan tipe mataair turbuler. Kuantitas (debit) 3 mataair tergolong kelas 7 8 dengan kualitas air pada seluruh sumber air bakteri coliform tinggi. Zona recharge berada pada bagian timur dan bagian barat di lokasi penelitian. Arahan teknik konservasi yang dilakukan secara agronomis pada daerah imbuhan dengan penanaman sistem wanatani, pembuatan saluran resapan dan rorak pada sistem teras gulud. Kemudian sistem mekanis di sempadan mataair yakni alat Chlorine Diffuser untuk mengatasi bakteri coliform, serta teknik bangunan penangkap air dari sumber air.
\end{abstract}

Kata kunci: Mataair, Teknik konservasi, Recharge, Karakteristik mataair, Agronomis

\begin{abstract}
In Sumberwatu and Dawangsari, three springs can be used to meet water needs. The three springs have not been able to meet the residents' needs during the dry season. The quality of water produced has also not been tested for clean water quality standards, so those conservation efforts are needed to increase the quantity and quality to meet the standards of clean water quality standards. This study aims to provide appropriate conservation techniques based on spring characteristics (type, quantity, and quality) and determine the location of recharge areas. Surveys, interviews, and mathematical methods are used to achieve research objectives. The processed aspects consist of topography, slope, community water needs, physical, chemical, and biological conditions of springs. From the data, these aspects are analyzed and interpreted to obtain the right conservation techniques. From the research, obtained that the springs are formed by the existence of gravity, with a type of springs is tubular springs. The quantity of the springs classified 7-8 class with water quality at all springs have a high quantity of coliform bacteria. The recharge zone is in the eastern and western sections of the study site. The conservation techniques applied in the recharge area are agronomic with wanatani systems, making the absorption channel and rorak on the gulud terrace system. Then the mechanical system at the border of the springs with chlorine diffuser for decrease the coliform bacteria, and then use public hydrants in the area of the border.
\end{abstract}

Keywords: Springs, Conservation technique, Recharge, Springs characteristic, Agronomic

Citation: Gibran, A. K., dan Kholid, N. I. (2020). Teknik Konservasi Mataair Berdasarkan Karakteristiknya : Studi Kasus Dusun Sumberwatu dan Dusun Dawangsari, Prambanan, di. Yogyakarta. Jurnal Ilmu Lingkungan, 18(2), 342-353, doi:10.14710/jil.18.2.342-353

\section{Latar Belakang}

Air memiliki banyak fungsi, sebagai pelarut umum, air digunakan oleh organisme untuk reaksireaksi kimia dalam proses metabolisme serta menjadi media transportasi nutrisi dan hasil metabolisme. Bagi manusia, air memiliki peranan yang sangat besar bukan hanya untuk kebutuhan biologisnya, yaitu bertahan hidup. Perubahan pola konsumsi masyarakat terjadi akibat semakin tingginya jumlah populasi penduduk dan laju perkembangan perkotaan (Kospa 2019). Sumber daya air di berbagai belahan dunia tidak hanya 
mengalami penurunan kuantitas akibat faktor perubahan iklim, namun juga tercemar oleh berbagai aktivitas ekonomi manusia (Jocom dkk., 2016).

Pemanfaatan air meliputi studi mengenai ketersediaan air dan kebutuhan air serta merencanakan fasilitas atau bangunan yang dapat memenuhi kebutuhan tersebut dari ketersediaan air yang ada. Kebutuhan manusia akan air diperoleh dari berbagai macam sumber, baik yang berupa air hujan, air permukaan maupun air tanah (Sudarmadji dkk., 2015). Dalam hal ini perlu diketahui jumlah dan kualitas air, waktu penyediaan, lokasi yang membutuhkan air dan sumber air (Triatmodjo, 2009). Pemanfaatan air yang paling utama digunakan untuk pemenuhan kebutuhan domestik, industri pertanian, peternakan, perikanan, rekreasi, dan lainnya. Kebutuhan air di suatu daerah perlu dihitung untuk mengetahui kecukupan sumberdaya air yang ada. Kebutuhan air dapat dihitung berdasarkan jenis pemanfaatannya (Sudarmadji dkk, 2014). Untuk melindungi mata air yang ada perlu dilakukan konservasi mataair (Riastika, 2011). Konservasi mataair adalah upaya melindungi dan memelihara keberadaan, kondisi, dan lingkungan air pada mataair guna mempertahankan kelestarian atau kesinambungan ketersediaan dalam kuantitas dan kualitas yang memadai, demi kelangsungan fungsi dan kemanfaatannya untuk memenuhi kebutuhan makhluk hidup, di waktu sekarang maupun pada generasi yang akan datang (Kodoatie, 2012). Arsyad, dkk. (2012) menyatakan bahwa, upaya konservasi air tanah yang sangat penting untuk dilakukan adalah rehabilitasi dan konservasi daerah resapan dalam upaya konservasi mataair.

Berdasarkan PP No 43 Tahun 2008, konservasi air tanah dapat dilakukan secara menyeluruh pada cekungan air tanah yang mencakup daerah imbuhan dan daerah lepasan air tanah, melalui:

1. perlindungan dan pelestarian air tanah;

2. pengawetan air tanah; dan

3. pengelolaan kualitas dan pengendalian pencemaran air tanah.

Riastika (2011) menjelaskan kegiatan-kegiatan perlindungan dan pelestarian air tanah yang dilakukan dapat berupa penetapan zona penambangan bahan tambang golongan $\mathrm{C}$, dan menghentikan kegiatan penambangan Galian C di wilayah prioritas, melakukan kegiatan konservasi secara agronomis, melakukan kegiatan konservasi secara mekanis, pengaturan daerah sempadan sumber air, pengendalian pengolahan tanah, pembuatan sumur resapan.

Pengawetan air tanah ditujukan untuk menjaga keberadaan dan kesinambungan ketersediaan air tanah. Pengawetan air tanah dilaksanakan dengan cara: 1. menghemat penggunaan air tanah; 2 . meningkatkan kapasitas imbuhan air tanah; dan/atau 3. mengendalikan penggunaan air tanah. Salah satu cara peningkatan kapasitas imbuhan air tanah melalui imbuhan buatan yang dapat dilakukan adalah dengan membuat sumur resapan.

Pengelolaan kualitas dan pengendalian pencemaran air tanah ditujukan untuk mempertahankan dan memulihkan kualitas air tanah sesuai dengan kondisi alaminya. Pengelolaan kualitas dan pengendalian pencemaran air tanah dilaksanakan dengan cara: 1. mencegah pencemaran air tanah; 2. menanggulangi pencemaran air tanah; dan/atau; 3. memulihkan kualitas air tanah yang telah tercemar, misalnya jika kandungan bakteri colliform melebihi batas baku mutu air dapat di konservasi menggunakan alat chlorine diffuser.

Desa Sambirejo, kecamatan Prambanan merupakan salah satu daerah yang termasuk daerah rawan kekeringan tingkat tinggi yang bersumber dari peta kerawanan bencana kekeringan Kabupaten Sleman (BPBD Kabupaten Sleman, 2017). Warga di Dusun Sumberwatu dan Dusun Dawangsari, Desa Sambirejo, Kecamatan Prambanan memanfaatkan mata air untuk kebutuhan air bersih. Mataair di Dusun Sumberwatu merupakan mataair yang mengalir sepanjang tahun. Akibat tidak adanya pengelolaan di daerah mataair dan kondisi daerah resapan mengakibatkan kuantitas air semakin menurun dan mengganggu kualitas air bersih yang dibutuhkan oleh masyarakat untuk kebutuhan sehari-hari. Tidak adanya pengelolaan daerah resapan dan buruknya kondisi biofisik sempadan mataair membuat pemunculan air pada mataair semakin tertutup yang menyebabkan penurunan kuantitas mataair. Salah satunya akibat adanya erosi di daerah penelitian. Selain itu, perlu adanya teknik konservasi mataair agar mataair dapat dimanfaatan secara maksimal dan mataair tetap terjaga fungsi dan manfaatnya untuk waktu sekarang sampai dengan waktu yang akan datang. Tujuan dari penelitian ini yaitu untuk mengetahui karakteristik mataair (tipe, kuantitas, dan kualitas), menentukan letak daerah imbuhan, dan mengetahui teknik konservasi yang cocok untuk mataair yang ada di daerah penelitian.

\section{Metode}

Lokasi penelitian berada di Desa Sambirejo, Kecamatan Prambanan, Kabupaten Sleman, Daerah Istimewa Yogyakarta. Tepatnya berada di Dusun Sumberwatu dan Dusun Dawangsari (Gambar 1). Penelitian mengenai konservasi terkait karakteristik dan potensi mataair di Desa Sambirejo, Kecamatan Prambanan, Kabupaten Sleman DIY menggunakan beberapa metode penelitian yaitu metode survey lapangan dan pemetaan, metode uji laboratorium, metode matematis, dan metode evaluasi. Metode survey dilakukan di lapangan dengan melakukan pengamatan, pengukuran, pencatatan hal-hal yang penting dan mengenai hal-hal yang berhubungan dengan hasil penelitian yang dilakukan secara sistematik terhadap fenomena yang terjadi di lapangan yang disebut data primer lalu mengkaitkan dengan data sekunder yang telah diperoleh 
sebelumnya yaitu data yang diperoleh dari instansi terkait di wilayah penelitian. Survei lapangan dilakukan untuk mendukung pemetaan dan wawancara di daerah penelitian. Wawancara dapat dilakukan secara terstruktur bila peneliti atau pengumpul data telah mengetahui dengan pasti tentang informasi yang akan diperoleh maupun tidak terstuktur yaitu dengan bebas. Penentuan banyaknya responden yang diambil menggunakan rumus slovin. Uji laboratorium dilakukan untuk mengamati kualitas air pada mataair di daerah penelitian, mengacu pada PERMENKES No. 416 Tahun 1990 tentang syaratsyarat dan pengawasan kualitas air. Parameter yang digunakan disesuaikan dengan kondisi lingkungan yang berpotensi melebihi bakumutu.

Metode matematis selanjutnya dilakukan untuk mengolah data setelah pengambilan data dilapangan, berisikan perhitungan dengan cara-cara, rumusrumus, dan kaidah-kaidah yang terkait. Pada penelitian ini perhitungan dilakukan untuk mengukur debit mataair, perhitungan besar kebutuhan air masyarakat, ketersediaan air tanah (neraca air) masyarakat, perhitungan pertambahan penduduk setiap tahunnya dan perhitungan prakiraan kebutuhan air dimasa yang akan datang.
Metode evaluasi merupakan metode akhir untuk dapat mencapai tujuan dari penelitian ini yaitu melakukan arahan konservasi yang sesuai pada daerah penelitian. Arahan tersebut didapatkan dari menganalisis hasil dari metode survey dan matematis.

\subsection{Bahan dan alat}

Perlengkapan yang akan digunakan pada penelitian ini disajikan pada tabel 1.

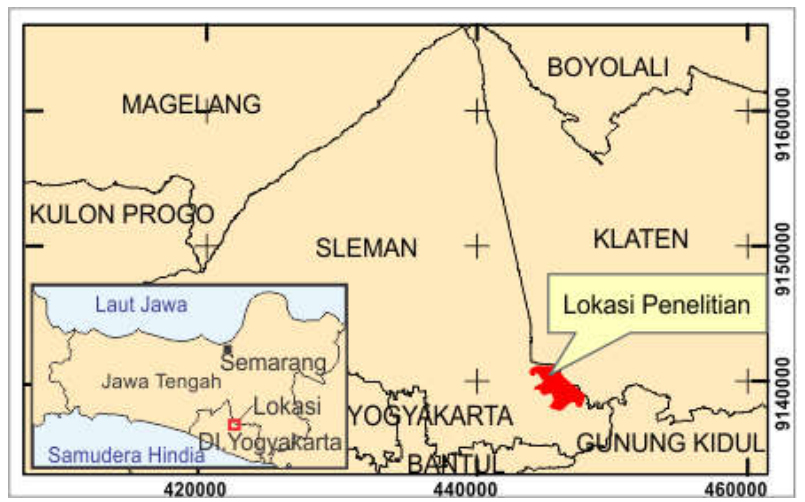

Gambar 1. Peta Lokasi Penelitian

Tabel 1. Perlengkapan Penelitian, Kegunaan, dan Hasil yang Didapat

\begin{tabular}{|c|c|c|c|}
\hline No. & Alat dan Bahan Penelitian & Kegunaan & Hasil \\
\hline \multirow[t]{7}{*}{1.} & Bahan & & \\
\hline & $\begin{array}{l}\text { a. Peta RBI lembar Timoho dan Jabung Skala } \\
1: 25.000\end{array}$ & Mengetahui topografi daerah penelitian & \multirow{6}{*}{$\begin{array}{l}\text { Sebagai peta dasar yang akan } \\
\text { digunakan saat tahap kerja } \\
\text { lapangan }\end{array}$} \\
\hline & $\begin{array}{l}\text { b. Peta RBI lembar Timoho dan Jabung Skala } \\
\text { 1:25.000 }\end{array}$ & $\begin{array}{l}\text { Tafsiran bentuklahan dan kemiringan } \\
\text { lereng }\end{array}$ & \\
\hline & c. Citra Google Earth & $\begin{array}{l}\text { Mengetahui penggunaan lahan daerah } \\
\text { penelitian }\end{array}$ & \\
\hline & $\begin{array}{l}\text { d. Peta RBI lembar Timoho dan Jabung Skala } \\
1: 25.000\end{array}$ & Mengetahui penggunaan lahan & \\
\hline & $\begin{array}{l}\text { e. Peta Geologi Lembar Yogyakarta, Jawa skala } \\
1: 100.000\end{array}$ & Mengetahui satuan batuan & \\
\hline & f. Peta Tanah Skala 1:100.000 & Mengetahui jenis tanah & \\
\hline \multirow[t]{13}{*}{2.} & Perlengkapan Penelitian di Lapangan & & \multirow{6}{*}{$\begin{array}{l}\text { Data analisis batuan } \\
\text { Data pembuatan peta tematik } \\
\text { Informasi titik penelitian } \\
\text { Data analisis batuan } \\
\text { Data analisis debit mataair dan } \\
\text { infiltrasi }\end{array}$} \\
\hline & a. $\mathrm{HCl} 0,1 \mathrm{~N}$ & Mengetahui kandungan karbonat & \\
\hline & b. Kompas Geologi & Menentukan kelurusan dan jurus batuan & \\
\hline & c. GPS & Menentukan posisi geografis & \\
\hline & d. Palu Geologi & Mengambil sampel batuan & \\
\hline & e. Penggaris & Mengukur tinggi air & \\
\hline & f. Stopwatch & Mencatat waktu & Data analisis debit mataair \\
\hline & g. Botol Sampel & Menyimpan sampel air dari mataair & Uji kualitas air dari mataair \\
\hline & h.Thermometer & Mengukur suhu air & $\begin{array}{l}\text { Uji kualitas fisik air dari } \\
\text { mataair }\end{array}$ \\
\hline & i. $\mathrm{pH}$ Strip & Mengukur pH air & $\begin{array}{l}\text { Uji kualitas fisik air dari } \\
\text { mataair }\end{array}$ \\
\hline & j. Infiltrometer & Mengetahui kapasitas infiltrasi & Data kapasitas infiltrasi \\
\hline & k. Kamera & $\begin{array}{l}\text { Mendokumentasikan survei dan kondisi } \\
\text { di lapangan }\end{array}$ & Informasi pendukung \\
\hline & 1. Alat tulis & Mencatat data & Informasi data tertulis \\
\hline \multirow[t]{4}{*}{3.} & Perlengkapan Penelitian di Studio & & \\
\hline & a.Komputer & Mengolah data dan peta & \multirow{3}{*}{$\begin{array}{l}\text { Laporan penelitian dan peta } \\
\text { Data perhitungan } \\
\text { Kualitas fisik, kimia, dan biologi } \\
\text { air }\end{array}$} \\
\hline & b.Kalkulator & Menghitung & \\
\hline & c.Alat uji laboratorium & Analisis kualitas air & \\
\hline
\end{tabular}

\section{Hasil dan Pembahasan}

\subsection{Karakteristik Mataair}

Air tanah merupakan sumber utama cadangan air tawar yang bekerja dalam siklus hidrostatik. Air tanah terdapat dalam batuan yang berada di bawah permukaan tanah meliputi keterdapatan, penyebaran dan pergerakan air tanah terkait kondisi geologi suatu daerah. Formasi batuan yang 
mengandung air bertindak sebagai penyalur atau reservoir (Permana, 2019). Air tanah yang muncul ke permukaan disebut mataair. Mataair merupakan air yang muncul ke permukaan karena beberapa faktor yang mempengaruhi seperti perubahan topografi, curah hujan, struktur geologi, penggunaan lahan, dan lain sebagainya. Faktor tersebut membuat karakteristik pada mataair berbeda-beda. Hal ini dapat mempengaruhi pemanfaatan, potensi maupun pengelolaan mataair. Karakterstik mataair yang dievaluasi meliputi sebaran, tipe mataair, dan kualitas.

\subsubsection{Sebaran Mataair}

Terdapat tiga mataair pada lokasi penelitian, di bagian paling utara ada Mataair Luwing, di bagian tengah ada Mataair Sumberwatu, dan terakhir di batian selatan terdapat Mataair Marikangen. Mataair tersebut terletak di ketinggian dan kemiringan lereng yang beragam pada morfologi perbukitan struktural. Mataair yang diteliti semuanya memiliki pemunculan mataair yang diakibatkan oleh adanya kekar di batuan atau disebut mataair turbuler yakni Mataair Luwing yang muncul pada kemiringan lereng miring di satuan breksi dengan lahan tegalan, dan Mataair Sumberwatu yang muncul pada kemiringan lereng miring pada satuan batupasir dengan penggunaan lahan tegalan, serta Mataair Marikangen yang muncul pada kemiringan lereng curam pada satuan breksi dengan penggunaan lahan tegalan.

Persebaran mataair menjadi penting untuk dapat dijangkau masyarakat dalam memenuhi kebutuhan air bersih sehari-hari terlebih yang menjadikan sumber air dari mataair tersebut kebutuhan utama, sehingga mudah dikelola pendistribusiannya ke masyarakat yang membutuhkan. Sebaran mataair dapat dilihat pada Gambar 2.

\subsubsection{Tipe Mataair}

Tipe mataair dikaji untuk mengetahui tipe mata air dalam penelitian, hal ini terkait sifat pengaliran, debit dan tenaga gravitasi di tiga mataair yang diteliti. Berikut adalah tipe mataair yang dikaji pada penelitian, tersaji pada Tabel 2. Sifat pengaliran ketiga mataair masuk ke dalam tipe mata air tahunan karena mataair ini tetap mengeluarkan air pada musim kemarau dan musim kemarau di lokasi penelitian rata-rata terjadi selama 5 bulan setiap tahunnya. Mataair yang diteliti berada diantara topografi miring hingga topografi curam. Airtanah keluar ke permukaan melalui rekahan-rekahan batuan dan celah-celah tanah. Penampang ketinggian muka airtanah dioverlay dengan penampang topografi, pengamatan satuan batuan, dan struktur batuan menjadikan dasar dari penentuan tipe mataair terhadap tenaga gravitasi. Hal ini dilakukan karena kondisi mataair di lapangan sulit untuk menentukan tipe mataair tersebut.

\subsection{Evaluasi Potensi Mataair}

Potensi mataair merupakan pendayagunaan dan pemanfaatan air pada mataair yang erat kaitannya dengan kuantitas (debit) dan kualitas airnya sebagai sumber air untuk memenuhi kebutuhan air masyarakat sehari-sehari. Analisis 2 hal tersebut memberikan informasi tentang ketersediaan air yang dimbangi oleh kebutuhan air masyarakat, sehingga dapat ditentukan ketersediaan air di lokasi penelitian untuk beberapa tahun kedepan dengan memproyeksikan pertumbuhan penduduk pada 10 tahun kedepan.

\subsubsection{Kuantitas (Debit) Air}

Terdapat tiga lokasi mata air pada lokasi penelitian, diantaranya yaitu Mata air Marikangen, Mata air Sumberwatu dan Mata air Sumber Luwing. Ketiga mata air tersebut selalu mengeluarkan air baik saat musim hujan maupun musim kering. Pada umumnya ketiga mata air tersebut dimanfaatkan warga untuk memenuhi kebutuhan sehari hari.

Pengukuran debit di setiap mataair dilakukan 5 kali dalam satu hari, kemudian didapatkan nilai ratarata debit pada Tabel 3. Klasifikasi kelas debit mengacu pada Meinzer (1923) yang mana dari tingkatan kelas 1-8, mata air sumberwatu dan mata air luwing termasuk kelas 8 yang berarti debit airnya sangat kecil sekali dan mata air marikangen termasuk kelas 7 yang berarti debit airnya sangat kecil.

\subsubsection{Kualitas Air}

Kualitas air sangat menentukan kesehatan manusia (Sulistyorini dkk., 2016). Uji kualitas air diambil dari bak penampungan air pada mata air, yang diambil pada musim penghujan. Hal ini menimbang tingkat pencemaran akan lebih terlihat, sedangkan secara kuantitas air yang muncul atau ketersediaan air akan melimpah dan secara otomatis lebih dimanfaatkan oleh masyarakat. Kemudian pengambilan sampel air dilakukan di tempat penampungan karena masyarakat langsung mengambil dan menggunakan air yang berada di bak penampungan, sehingga jika air pada bak penampungan tersebut diuji maka dapat diketahui kandungan air yang membahayakan masyarakat.

Uji sampel air dilakukan pada laboratorium yang bertempat di Balai Pengujian, Informasi Pemukiman dan Bangunan dan Pengembangan Jasa Konstruksi (Balai PIPBPJK) DIY. Parameter-parameter yang duiji meliputi sifat fisik (warna, bau, dan kekeruhan), sifat kimia ( $\mathrm{pH}, \mathrm{Fe}$, nitrit, dan nitrat), dan sifat biologi (bakteri total coliform). Parameter-parameter tersebut khususnya pada sifat kimia dan biologi ditetapkan berdasarkan penggunaan lahan disekitar mataair. Kualitas air dapat dilihat pada Tabel 4 . Penjabaran dari hasil laboratorium yang telah dilakukan. 
Tabel 2. Tipe Mataair Pada Lokasi Penelitian

\begin{tabular}{clll}
\hline \hline No. & \multicolumn{1}{c}{ Sumber Air } & Sifat Pengaliran & Tenaga Gravitasi \\
\hline 1 & Mataair Luwing & Mata air tahunan & Mataair turbuler \\
2 & Mataair Sumberwatu & Mata air tahunan & Mataair turbuler \\
3 & Mataaair Marikangen & Mata air tahunan & Mataair turbuler \\
\hline
\end{tabular}

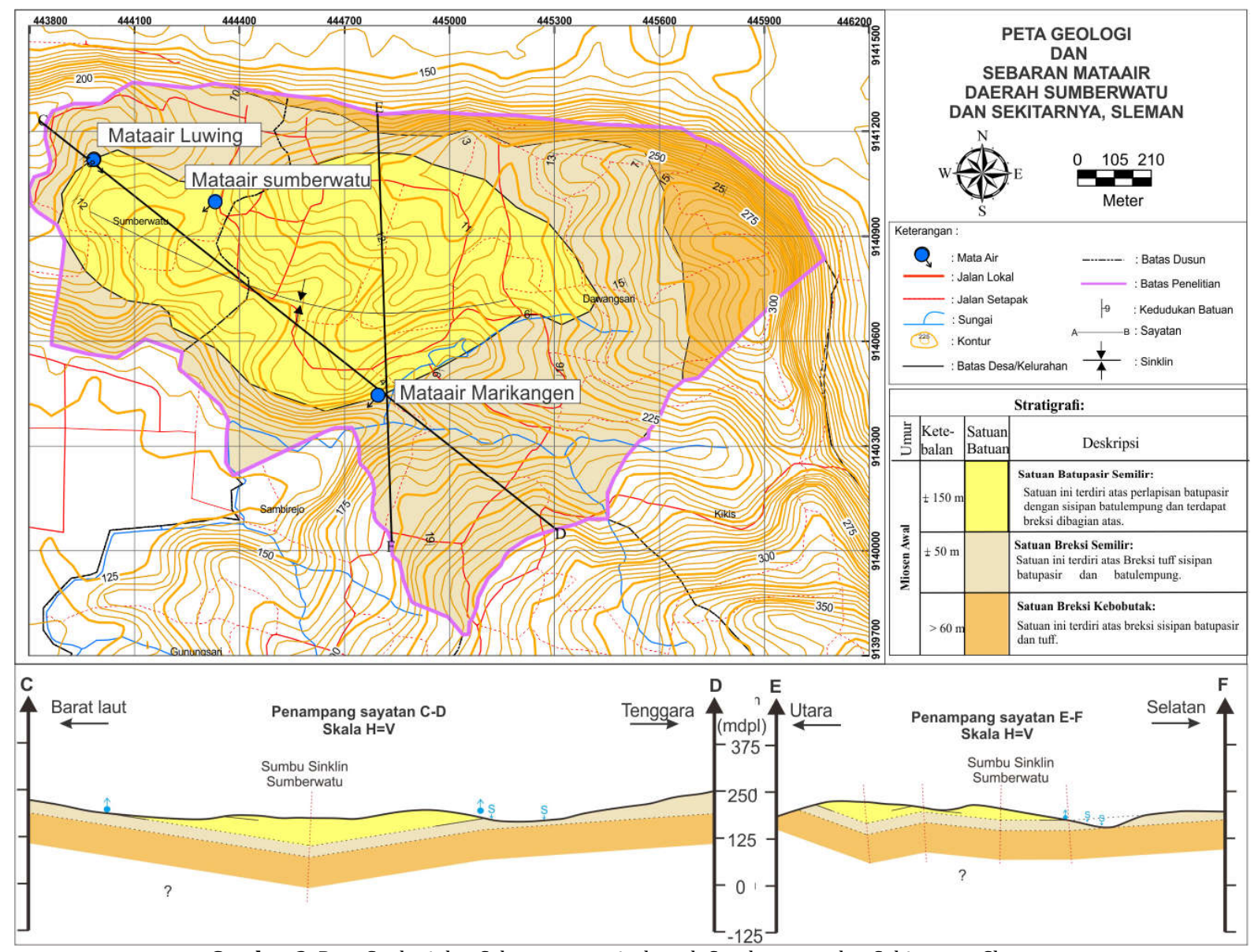

Gambar 2. Peta Geologi dan Sebaran mataair daerah Sumberwatu dan Sekitarnya, Sleman.

Tabel 3. Kelas Debit Mata air

\begin{tabular}{ccccccccc}
\hline \hline \multirow{2}{*}{ No. } & \multirow{2}{*}{ Sumber Air } & \multicolumn{9}{c}{ Debit Rata-rata } & Kelas & \multirow{2}{*}{ Arti } \\
\cline { 3 - 6 } & & $\mathrm{ml} /$ det & $\mathrm{ml} / \mathrm{jam}$ & $\mathrm{ml} / \mathrm{hari}$ & $\mathrm{ml} /$ tahun & $\mathrm{l} /$ tahun & Debit $(*)$ & Sangat Kecil Sekali \\
\hline 1 & Mataair Luwing & 0,0023167 & 8,34 & 200,16 & $73.058,51$ & 73,06 & 8 & Sangat Kecil Sekali \\
2 & Mataair Sumberwatu & 8,16 & 29.376 & 705024 & 257.333 .760 & $257.333,76$ & 8 & Sangat Kecil \\
\hline
\end{tabular}

Tabel 4. Data Kualitas Air

\begin{tabular}{|c|c|c|c|c|c|}
\hline \multirow[b]{2}{*}{ Parameter } & \multirow[b]{2}{*}{ Satuan } & \multicolumn{3}{|c|}{ Hasil Uji Kualitas } & \multirow{2}{*}{$\begin{array}{c}\text { Baku Mutu Air } \\
\text { Permenkes No. } 416 \\
\text { tahun } 1990\end{array}$} \\
\hline & & Mataair Luwing & Mataair Sumberwatu & Mataair Marikangen & \\
\hline \multicolumn{6}{|c|}{ FISIK } \\
\hline Warna & - & Tidak berwarna & Tidak berwarna & Tidak berwarna & Tidak berwarna \\
\hline $\mathrm{Bau}$ & - & Tidak berbau & Tidak berbau & Tidak berbau & Tidak Berbau \\
\hline Kekeruhan & FTU & 1,39 & 0,83 & 0,65 & 5 \\
\hline \multicolumn{6}{|c|}{ KIMIA } \\
\hline $\mathrm{pH}$ & & 7 & 7 & 7 & $6,5-9$ \\
\hline $\mathrm{Fe}$ & $\mathrm{mg} / \mathrm{L}$ & 0,66 & 0,44 & 0,001 & 1 \\
\hline Nitrat & $\mathrm{mg} / \mathrm{L}$ & 2,36 & 2,51 & 2,85 & 10 \\
\hline \multicolumn{6}{|c|}{ BIOLOGI } \\
\hline Bakteri Coliform & $\mathrm{JPT} / 100 \mathrm{~mL}$ & $4,3 \times 10^{4}$ & $7 \times 10^{1}$ & $1,5 \times 10^{2}$ & 50 \\
\hline
\end{tabular}

Keterangan: Cetak tebal $=$ diatas ambang bakumutu

\subsubsection{Sifat Fisik (warna, bau, kekeruhan)}

Sifat fisik merupakan sifat yang terlihat secara kasat mata dan panca indera. Penurunan kualitas air ditandai dengan perubahan warna air dan bau (Pohan dkk., 2016). Hasil uji laboratorium untuk Air mata air pada mata air luwing, mata air sumberwatu, dan mata air marikangen tidak berwarna dan tidak berbau. Nilai kekeruhan mata air luwing 1,39 NTU, mata air 
sumberwatu 0,83 NTU, dan mata air marikangen 0,65 NTU, semua mata air berada dibawah bakumutu.

\subsubsection{Sifat Kimia}

Hasil pengukuran di lapangan dan hasil uji laboratorium kualitas kimia air dari mata air akan dibahas lebih lanjut dibawah ini:

\subsubsection{1. pH (potential hydrogen)}

$\mathrm{pH}$ adalah salah satu faktor terpenting yang melayani indeks untuk polusi. pH memiliki efek langsung pada kehidupan di ekosistem (Sari dan Wijaya, 2019). Pengaruh pH terhadap air bervariasi. $\mathrm{pH}$ air yang terlalu rendah (asam) akan menimbulkan rasa pahit/asam, sedangkan air yang memiliki $\mathrm{pH}$ terlalu tinggi (basa) akan berasa tidak enak (kental/licin) seperti sabun. Berdasarkan tabel 4 mata air luwing, mata air sumberwatu, dan mata air marikangen memiliki nilai $\mathrm{pH}$ 7. Bakumutu air berdasarkan Permenkes No. 416 tahun 1990 nilai yang diperbolehkan yaitu 6,5 - 9, sehingga ketiga mata air tersebut masih sesuai bakumutu.

\subsection{Besi (Fe)}

Berdasarkan tabel 4 mata air luwing memiliki nilai Fe sebesar 0,66 mg/L, mata air sumberwatu memiliki nilai Fe sebesar 0,44 mg/L, dan mata air marikangen memiliki nilai Fe terkecil yaitu $<0,001$ mg/L. Bakumutu air berdasarkan Permenkes No. 416 tahun 1990 nilai yang diperbolehkan maksimal 1 $\mathrm{mg} / \mathrm{L}$, sehingga air dari seluruh mata air masih dibawah bakumutu.

\subsection{Nitrat}

Berdasarkan tabel 4 mata air luwing memiliki nilai nitrat sebesar 2,36 mg/L, mata air sumberwatu memiliki nilai nitrat sebesar $2,51 \mathrm{mg} / \mathrm{L}$, dan mata air marikangen memiliki nilai nitrat sebesar 2,85 mg/L. Bakumutu air berdasarkan Permenkes No. 416 tahun 1990 nilai maksimal yang diperbolehkan $10 \mathrm{mg} / \mathrm{L}$, sehingga air dari seluruh mata air masih dibawah bakumutu. Kadar nitrat dalam mata air tergantung aktivitas sumber pencemar di bagian hulu(aktivitas pertanian dan hewan).

\subsubsection{Sifat Biologi}

Coliformtotal merupakan nilai total atau kumpulan dari berbagai jenis bakteria yang ada di dalam sampel air yang diujikan. Coliform total merupakan salah satu indikator akan keberadaan pathogen di suatu perairan seperti virus, protozoa, dan parasit (Yogafanny, 2015). Berdasarkan tabel 4 mata air luwing memiliki nilai bakteri coliform sebesar 4,3×104 JPT/100 mL, mata air sumberwatu memiliki nilai bakteri coliform sebesar 7x10 $0^{1} \mathrm{JPT} / 100 \mathrm{~mL}$, dan mata air marikangen memiliki nilai bakteri coliform sebesar 1,5×102 JPT/100 mL. Bakumutu air berdasarkan Permenkes No. 416 tahun 1990 nilai maksimal yang diperbolehkan $50 \mathrm{JPT} / 100 \mathrm{~mL}$, sehingga air dari seluruh mata air melebihi bakumutu. Sumber bakteri coliform yang terkandung pada ketiga mataair dapat berasal dari kotoran hewan, dimana lokasi mataair yang belum ada perlindungan dari kotoran hewan, serta pengelolaan sumber mataair dan bak penampung air dari mataair yang sangat sederhana sehingga mataair masih sangat rentan terpengaruh oleh kotoran hewan. Mataair dilokasi penelitian memiliki kadar coliform yang melebihi bakumutu sehingga pelu dilakukan penanganan.

\subsubsection{Kebutuhan Air Masyarakat}

Kebutuhan air masyarakat dihitung berdasarkan alokasi air. Alokasi Air merupakan suatu kegiatan pengaturan pemberian air dalam jumlah volume/kuantitas dan waktu tertentu yang didasarkan atas ketersediaan dan kebutuhan air menurut jenis, volume dan waktu tertentu yang disesuaikan dengan hasil kesepakatan urutan prioritasnya (Taufik dkk., 2020). Kebutuhan air di Dusun Sumberwatu dan Dawangsari terdiri dari kebutuhan domestik seperti minum, memasak, mandi, dan mencuci, lalu kebutuhan non domestik seperti peternakan dan industri rumah tangga. Untuk mengetahui jumlah kebutuhan-kebutuhan air tersebut dapat diketahui dengan menggunakan metode wawancara kepada masyarakat yang memanfaatkan mata air yang diteliti baik sebagai sumber air utama maupun tambahan, sehingga jumlah masyarakat yang diwawancara hanya masyarakat pengguna masing-masing mata air tersebut. Setelah mengetahui jumlahnya, selanjutnya akan dikalkulasikan dengan kebutuhan air keluarga/hari.

Mata air yang diteliti digunakan oleh warga dusun akan tetapi tidak semua warga dusun tersebut menggunakan air dari mata air tersebut. Dari hasil survey dan wawancara diketahui kebutuhan air domestik dan non domestik pada mata air yang diteliti tersaji pada Tabel 5 .

\subsubsection{Proyeksi Jumlah Penduduk}

Proyeksi penduduk bertujuan untuk mengetahui kemampuan mata air dalam memenuhi kebutuhan air masyarakat di 10 tahun kedepan dengan kondisi mata air yang seperti sekarang. Proyeksi jumlah penduduk menggunakan metode geometrik atau bunga berganda. Laju pertumbuhan penduduk menurut data BPS tahun 2016 di Kecamatan Prambangan pada tahun 1971 - 1980, 1980 - 1990, 1990 - 2000, 2000 2010, berturut - turut adalah 1,10\%, 0,57\%, 0,72\%, dan $1,04 \%$. Laju pertumbuhan penduduk yang digunakan menggunakan laju pertumbuhan penduduk yang paling besar, yaitu 1,10\%. Sehingga didapatkan nilai proyeksi jumlah pertumbuhan penduduk dalam 10 tahun terakhir pada Tabel 6 . Perhitungan dapat dilihat pada lampiran 3.

Contoh perhitungan perkiraan jumlah penduduk:

Dusun Sumberwatu tahun

$$
\begin{aligned}
\mathrm{P}_{2027} & =335(1+0,011)^{10} \\
& =374 \text { jiwa } \\
\text { Dusun } & \text { Dawangsari } \\
\mathrm{P}_{2027} & =502(1+0,011)^{10} \\
& =560 \text { jiwa }
\end{aligned}
$$


Proyeksi jumlah penduduk ditahun 2027 akan dibandingkan dengan jumlah debit mataair sampai 10 tahun ke depan dengan harapan masih dapat mencukupi kebutuhan air penduduk seiring peningkatan penduduk ditahun 2027. Kebutuhan air untuk tahun 2027 sesuai dengan proyeksi penduduk yang diteliti dapat dilihat pada Tabel 7.

Tabel 5. Kebutuhan Air Masyarakat

\begin{tabular}{|c|c|c|c|c|c|c|}
\hline \multirow[t]{2}{*}{ Sumber Air } & \multirow{2}{*}{$\begin{array}{l}\text { Dusun yang } \\
\text { memanfaatkan }\end{array}$} & \multirow[t]{2}{*}{ Jenis Kebutuhan Air } & \multicolumn{4}{|c|}{ Kebutuhan Air } \\
\hline & & & $\begin{array}{l}\text { Per KK } \\
\text { (l/hari) }\end{array}$ & $\begin{array}{l}\text { Per Orang } \\
\text { (l/hari) }\end{array}$ & $\begin{array}{l}\text { SNI-03-7065-2005- } \\
\text { plambing, }\end{array}$ & $\begin{array}{c}\text { Permen PU } \\
\text { 14/PRT/M/2010 }\end{array}$ \\
\hline \multirow{4}{*}{$\begin{array}{l}\text { Mata air Luwing } \\
\text { dan Mata air } \\
\text { Sumberwatu }\end{array}$} & \multirow{4}{*}{$\begin{array}{c}\text { Dusun } \\
\text { Sumberwatu }\end{array}$} & Minum & 6,67 & 1,85 & & \\
\hline & & Masak & 5,19 & 0,78 & & \\
\hline & & $\begin{array}{l}\text { Mandi, Mencuci, dan } \\
\text { Kakus }\end{array}$ & 210,73 & 24,53 & & \\
\hline & & Total & 222,59 & 27,16 & & \\
\hline \multirow{4}{*}{$\begin{array}{l}\text { Mata } \\
\text { Marikangen }\end{array}$} & \multirow{4}{*}{$\begin{array}{c}\text { Dusun } \\
\text { Dawangsari }\end{array}$} & Minum & 7,29 & 1,99 & & \\
\hline & & Masak & 5,15 & 0,71 & & \\
\hline & & $\begin{array}{l}\text { Mandi, Mencuci, dan } \\
\text { Kakus }\end{array}$ & 200,03 & 23,49 & & \\
\hline & & Total & 212,47 & 26,19 & 120 & 60 \\
\hline
\end{tabular}

\subsubsection{Imbangan air}

Perhitungan imbangan air dilakukan guna untuk mengetahui mata air mampu mencukupi kebutuhan air warga apa tidak. Data tersebut tertera pada tabel 8 yang berisi perhitungan imbangan airnya. Berdasarkan tabel tersebut, perhitungan yang didapat pada tahun 2017 dan tahun 2027 terjadi defisit atau kekurangan air, jadi mata air tidak mampu memenuhi kebutuhan air masyarakat. Kekurangan air yang dialami oleh masyarakat dipenuhi dengan adanya air PDAM serta adanya pembelian air lewat truk tangki yang diambil dari daerah lain dengan cara iuran antar masyarakat.

Tabel 6. Perkiraan Jumlah Penduduk Pada Tahun 2027

\begin{tabular}{ccccc}
\hline \hline No. & Dusun & $\begin{array}{c}\text { Pertumbuhan } \\
\text { Penduduk }\end{array}$ & $\begin{array}{c}\text { Jumlah Jiwa } \\
\text { Tahun 2017 }\end{array}$ & $\begin{array}{c}\text { Jumlah Jiwa } \\
\text { Tahun 2027 }\end{array}$ \\
\hline 1 & Sumberwatu & $1,1 \%$ & 335 & 374 \\
2 & Dawangsari & $1,1 \%$ & 502 & 560 \\
\hline
\end{tabular}

Tabel 7. Kebutuhan Air Masyarakat Terhadap Sumber Air yang Diteliti Tahun 2027

\begin{tabular}{|c|c|c|c|c|}
\hline \multirow{2}{*}{ Jenis Kebutuhan Air } & \multicolumn{2}{|c|}{ Kebutuhan Air Dusun Sumberwatu (L/Tahun) } & \multicolumn{2}{|c|}{ Kebutuhan Air Dusun Dawangsari (Liter/Tahun) } \\
\hline & 2017 & 2027 & 2017 & 2027 \\
\hline Minum & $225.688,43$ & $251.779,78$ & $365.495,63$ & $407.724,21$ \\
\hline Masak & $95.141,93$ & $106.141,08$ & $129.566,33$ & $144.536,15$ \\
\hline $\begin{array}{l}\text { Mandi, Mencuci, dan } \\
\text { Kakus }\end{array}$ & 2999374,7 & 3346125,91 & 4303196,51 & 4800378,59 \\
\hline Total & $3.320 .205,06$ & $3.704 .046,77$ & $4.798 .258,47$ & $5.352 .638,95$ \\
\hline
\end{tabular}

Tabel 8. Perhitungan imbangan air di dusun Sumberwatu dan Dawangsari pada tahun 2017 dan 2027

\begin{tabular}{|c|c|c|c|c|}
\hline Nama Dusun pada tahun & $\begin{array}{c}\text { Total Debit mataair } \\
\text { (L/tahun) }\end{array}$ & $\begin{array}{c}\text { Total kebutuhan air } \\
\text { (L/tahun) }\end{array}$ & Imbangan Air & Keterangan \\
\hline Dusun Sumberwatu (2017) & $257.406,82$ & $3.320 .205,06$ & $-3.062 .798,241$ & Defisit \\
\hline Dusun Sumberwatu (2027) & $257.406,82$ & $3.704 .046,77$ & $-3.446 .639,95$ & Defisit \\
\hline Dusun Dawangsari (2017) & $1.212 .874,56$ & $4.798 .258,47$ & - 3.585.383,911 & Defisit \\
\hline Dusun Dawangsari (2027) & $1.212 .874,56$ & $5.352 .638,95$ & $-4.139 .764,39$ & Defisit \\
\hline
\end{tabular}

\subsection{Evaluasi Daerah Imbuhan}

Daerah imbuhan merupakan daerah yang berfungsi untuk meresapkan air mengisi air tanah. Daerah imbuhan atau recharge area sangat penting dan mengontrol kualitas dan kuantitas air tanah sebagai pemasok air pada sumber air yang dapat digunakan warga dalam memenuhi kebutuhan masyarakat sekitar. Dalam mengevaluasi daerah imbuhan hal yang paling penting adalah penggunaan lahan yang diprioritaskan seperti lahan hutan, kebun, dan lahan-lahan lainnya yang banyak memiliki tanaman penutup. Parameter lainnya seperti curah hujan, kemiringan lereng, dan tekstur tanah disesuai dengan Peraturan Mentri PU No.2 Tahun 2013 tentang Penentuan Daerah Imbuhan. Daerah imbuhan lokasi penelitian dapat dilihat pada Gambar 3.

Debit mataair di daerah penelitian keduanya tergolong kecil. Tingkat curah hujan yang sedang di daerah penelitian semestinya dapat memberi pasokan air tanah yang sedang pula. Apabila ketersediaan air tanah semakin tahun semakin menurun, maka debit mataair juga berpotensi semakin kecil. Oleh karena 
itu, perlu diketahui kondisi daerah imbuhan sebagai upaya melestarikan keberadaan sumber air pada lokasi penelitian. Penentuan daerah imbuhan mengacu pada Peraturan Mentri PU No.2 Tahun 2013 yang terdiri dari variabel berupa analisa curah hujan, analisa penggunaan lahan, analisa kemiringan lereng, dan analisa tekstur tanah.

Peta Isohyet lokasi penelitian memberikan informasi bahwa Dusun Sumberwatu dan Dusun Dawangsari, Desa Sambirejo, Kec. Prambanan, Kab. Slman, D.I. Yogyakarta memiliki nilai curah hujan 1060-1180 mm/tahun (Gambar 3). Pada klasifasi daerah imbuhan Peraturan Mentri PU No.2 Tahun 2013 menandakan bahwa lokasi penelitian memiliki curah hujan sedang, hal ini akan memberikan potensi resapan air yang cukup.

Penggunaan lahan memberikan banyak peran penting terhadap daerah imbuhan. Penggunaan lahan yang memiliki banyak tanaman penutupnya maka akan dapat mengurangi run off atau limpasan permukaan yang membuat air tidak dapat masuk kedalam tanah secara optimal. Tanaman penutup juga bermanfaat mengurangi jatuhan langsung air hujan yang dapat merusak agregat tanah. Dengan demikian jenis penggunaan lahan seperti semak, tegalan, dan kebun pada lokasi penelitian merupakan daerah yang mampu meresap air lebih tinggi dibandingkan penggunaan lahan lainnya seperti pemukiman.

Pada klasifikasi daerah imbuhan menurut Peraturan Mentri PU No.2 Tahun 2013 terkait kemiringan lereng terbagi menjadi 5 kelas kemiringan lereng (Gambar 4). Kemiringan lereng yang datar dengan nilai $0-5 \%$ hingga kemiringan topografi yang terjal yaitu lebih dari 60\%. Kemiringan lereng dengan nilai lebih dari $60 \%$ berada pada utara dan timur daerah penelitian. Kemudian letak kelas kemiringan lereng agak curam dengan nilai kemiringan lereng 20$40 \%$ berada di selatan, timur, dan sedikit di barat daerah penelitian. Selanjutnya daerah dengan daerah resapan yang baik dengan nilai kemiringan lereng 0 $5 \%$ yang berarti topografi datar berada pada barat daerah penelitian, dan kemampuan resapan yang cukup baik terletak pada kemiringan lereng miring (5$20 \%$ ) yang letaknya beriringan dengan topografi yang datar dan sedikit dibagian barat dan tengah. Dengan demikian, kemiringan lereng miring dengan kemampuan daerah resapan cukup baik dan kemiringan lereng agak curam dengan kemampuan daerah resapan sedang mendominasi pada daerah penelitian.

Selain dikaji dari tiga aspek tadi, penentuan daerah imbuhan juga perlu mengkaji tekstur tanah pada lokasi penelitian. Tekstur tanah dibedakan berdasarkan jenis tanah dan satuan batuan. Dengan kata lain tiap jenis tanah memiliki kelas tekstur yang berbeda pula, tergantung pada faktor yang mempengaruhinya seperti bahan induk, iklim, dan topografi. Daerah yang memiliki tekstur tanah berupa pasir akan memiliki kemampuan resapan air yang lebih tinggi dibandingkan dengan tekstur tanah berupa lempung.

Kondisi daerah imbuhan dengan variabel penentunya menurut Peraturan Mentri PU No.2 tahun 2013 yang diterapkan pada lokasi penelitian dapat dilihat pada Tabel 9.

Tabel 9. Variabel Daerah Imbuhan Dusun Sumberwatu dan Dusun Dawangsari

\begin{tabular}{|c|c|c|c|}
\hline No & $\begin{array}{c}\text { Variabel } \\
\text { Daerah Imbuhan }\end{array}$ & $\begin{array}{l}\text { Kemampuan Resapan Air } \\
\text { Lokasi Penelitian }\end{array}$ & Letak pada Lokasi Penelitian \\
\hline 1 & Curah hujan & $\begin{array}{c}\text { Sedang } \\
(1060-1180 \mathrm{~mm} / \text { tahun })\end{array}$ & Seluruh Dusun Sumberwatu dan Dusun Dawangsari \\
\hline 2 & Kemiringan Lereng & $\begin{array}{c}\text { Baik } \\
\text { (topografi miring - agak curam } 7 \%-60 \% \text { ) }\end{array}$ & Timur dan barat Dusun Sumberwatu dan Dusun Dawangsari \\
\hline 3 & Penggunaan Lahan & $\begin{array}{c}\text { Sedang } \\
\text { (ladang-kebun campuran) }\end{array}$ & Timur dan barat Dusun Sumberwatu dan Dusun Dawangsari \\
\hline 4 & Tekstur Tanah & $\begin{array}{l}\text { Sedang } \\
\text { (Pasir Geluhan, Geluh Lempungan) }\end{array}$ & Barat higga timur Dusun Sumberwatu dan Dusun Dawangsari \\
\hline
\end{tabular}

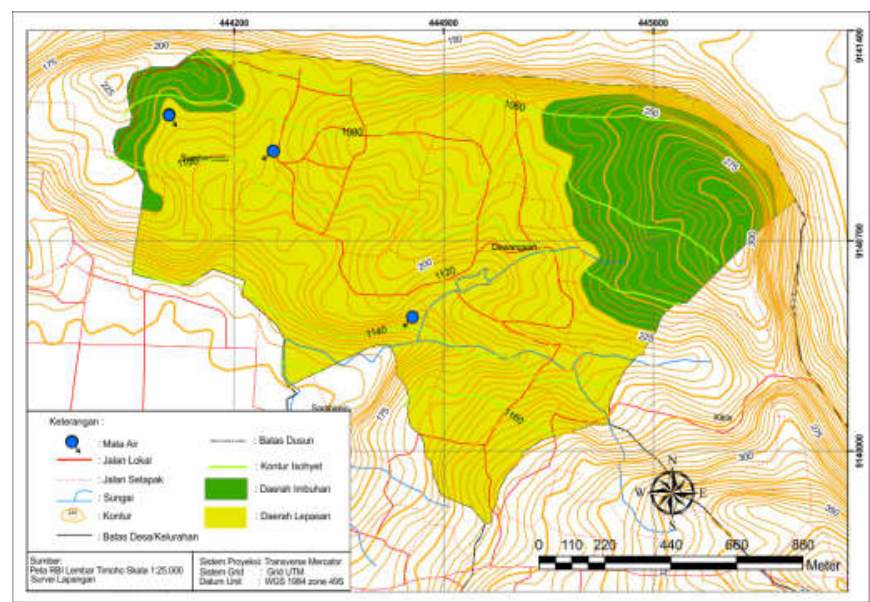

Gambar 3. Peta Daerah Imbuhan dan Lepasan Mata Air yang dikombinasikan dengan kontur isohyet Dusun Sumberwatu dan Dusun Dawangsari, Desa Sambirejo, Kecamatan Prambanan, Kabupaten Sleman, D.I. Yogyakarta 


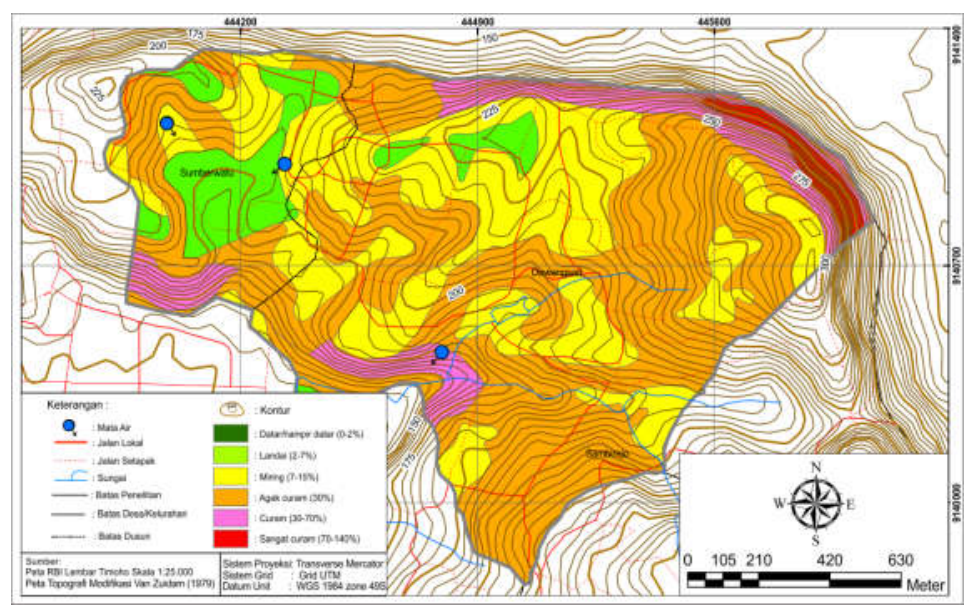

Gambar 4. Peta Kemiringan lereng Dusun Sumberwatu dan Dusun Dawangsari, Desa Sambirejo, Kecamatan Prambanan, Kabupaten Sleman, D.I. Yogyakarta.

\subsection{Teknik Konservasi Daerah Imbuhan}

Daerah imbuhan sangat berpengaruh terhadap kuantitas air pada sumber air, sedangkan pada lokasi penelitian sudah terjadi ketidak seimbangan debit sumber air dengan banyak kebutuhan warga disekitar mataair. Hal ini menandakan banyak diantara sumber air tersebut memiliki debit yang kecil. Lokasi penelitian dengan beberapa variabel dalam menentukan daerah imbuhan tergolong memiliki lahan resapan air yang sedang, walaupun curah hujannya tinggi. Oleh karena itu perlu adanya konservasi pada daerah imbuhan agar kondisi potensi air sumber air dapat membaik.

Konservasi dilakukan dengan pendekatan teknik agar dapat meningkatkan kegunaan daerah resapan lebih baik. Tujuan utama dari konservasi yang direncanakan yaitu melindungi tanah dari hantaman air hujan dengan vegeratsi penutup permukaan tanah, dan mengurangi run off sekaligus mengurangi kecepatan alirannya sehingga diharapkan air lebih banyak masuk kedalam tanah. Upaya konservasi terkait variabel yang ada, yaitu penggunaan lahan dan tekstur tanah menjadi perhatian dalam melakukan pengelolaan. Teknik konservasi matair dilakukan pada daerah imbuhan maupun daerah sempadan mataair seluas $200 \mathrm{~m}$ disekitar mataair. Teknik konservasi yang dapat direalisasikan diantaranya konservasi secara mekanis. Konservasi secara kimia tidak dipilih karena kurang efektifnya terhadap konservasi air. Sehingga diterapkan teknik konservasi sebagai berikut:

\subsubsection{Konservasi Secara Mekanis}

Konservasi ini lebih mengutamakan pendekatan teknik dalam pengelolaannya. Usaha konservasi yang sesuai untuk lokasi penelitian yaitu:

\subsubsection{Saluran resapan dan rorak pada sistem teras gulud}

Saluran peresapan adalah saluran yang dibuat untuk menahan sementara air aliran permukaan pada bidang lahan sehingga air meresap ke dalam tanah. Biasanya saluran resapan dilengkapi dengan rorak 350 untuk memaksimalkan serapan air dan untuk menampung sedimen. Pada teras gulud saluran peresapan dibuat di lereng atas dari gulud sedangkan pada teras bangku pada dasar tampingan teras. Rorak adalah tempat penampungan dan peresapan air dibuat di bidang olah atau di saluran peresapan. Rorak memperbesar peresapan air ke dalam tanah dan menampung tanah tererosi. Umumnya rorak berukuran panjang 0,5 - $1 \mathrm{~m}$, lebar $25-50 \mathrm{~cm}$ dan dalam $25-50 \mathrm{~cm}$. Yang harus diwaspadai dalam penerapan rorak dan teknologi pemanenan air lainnya adalah bahwa air hanya boleh tergenang beberapa saat. Apabila penggenangan berlanjut, dikhawatirkan akan terjadi masalah berupa penyakit yang menyerang melalui akar tanaman. Pada daerah bercurah hujan tinggi dan kadar liat tanah tinggi, pembuatan rorak dapat menyebabkan penggenangan yang berlanjut. Tekstur Tanah di daerah imbuhan yang berupa pasir geluhan bisa dilakukan pembuatan rorak, karena tekstur pasir yang cenderung mudah meloloskan air sehingga air tidak terlalu lama menggenang didalam rorak.

\subsection{Teknik Pengelolaan Daerah Sempadan Mataair}

Sumber air dikatakan berpotensi baik dalam memenuhi kebutuhan air masyarakat itu berarti secara kualitas maupun kuantitas airnya baik, yang selain dikontrol oleh daerah imbuhan yang perlu dijaga tetapi juga dikontrol oleh daerah sempadan mataair. Daerah sempadan mataair sangat rawan dipicu oleh aktivitas manusia yang dapat mempengaruhi kualitas maupun kuantitas air. Disebut daerah sempadan mataair menurut Peraturan Mentri PU dan Perumahan Rakyat Republik Indonesia No 28 Tahun 2015 yakni area seluas $200 \mathrm{~m}$ sekitar mataair. Penelitian ini melakukan konservasi selain dari sisi suplai tapi juga dari sisi efisiensi penggunaan air dengan pengelolaan bangunan sumber air seperti penangkap mataair, jaringan transmisi, dan jaringan distribusi.

Pengelolaan bangunan sumber air yang baik untuk lokasi penelitian diantaranya terdiri dari alat 
bantu dengan konsep filter penyaringan air untuk menurunkan kualitas air yang tinggi, serta pembuatan bak penampung agar sistem pendistribusiannya terpenuhi sebagai bak penampungan air dari sumber air.

\subsubsection{Filter Penurun Kadar Coliform}

Kualitas air yang tinggi kandungan coliform berdampak pada kesehatan masyarakat hingga pada parameter tertentu dapat mengakibatkan kematian. Hasil dari analisis bilogi mataair menunjukkan Kualitas air yang tinggi kandungan bakteri coliform di semua sumber air yang tinggi. Oleh karena itu dibuat alat untuk menurunkan kadar air tersebut mengingat efeknya terhadap kesehatan masyarakat yang berbahaya. Berdasarkan kondisi di lapangan warga sekitar mataair adalah pekerjaan mereka didominasi oleh pekerja kasar seperti buruh di tambang batu, tukang batu, dan petani dengan pendidikan rendah, sehingga dibutuhkan alat yang mudah dibuat dan mudah dirawat dengan harga yang ekonomis. Alat yang digunakan adalah Chlorine Diffuser. Alat ini dapat menjawab kebutuhan warga tersebut. Alat ini mudah dibersihkan dan dirawat oleh warga sekitar. Alat tersebut merupakan alat yang sederhana dalam pengelolaan air dengan tujuan membunuh kuman atau bakteri pantogen yang ada di dalam air dengan menggunakan bahan desinfektan berupa kaporit $\mathrm{Ca}(\mathrm{ClO})_{2}$. Alat ini digunakan karena diseluruh mataair bakteri Coliform melebihi bakumutu yang ada, sehingga menggunakan alat ini guna untuk menurunkan kadar bakteri Coliform yang ada pada air mataair. Untuk memudahkan dalam membubuhkan kaporit dibuat alat. Alat ini dapat dibuat menggunakan 2 pipa pvc, pipa pertama ukuran 2 in diisi pasir kasar dan pipa kedua menggunakan pipa pvc ukuran 1,25in yang sudah diletakkan di dalam pipa pertama, pipa ke dua diisi campuran pasir dan kaporit kemudian diberi lubang-lubang halus. Penggunaan alat ini yaitu dipasang pada setengah ketinggian/kedalaman bak.

\subsubsection{Bak Penampung}

Pembuatan bak penampung merupakan bangunan penangkap mataair yang dapat melindungi mataair terhadap pencemaran atau faktor pemicu dari aktivitas manusia dan gangguan lingkungan lainnya seperti adanya bidang longsor yang dapat mengganggu pemunculan air mataair, kuantitas, maupun kualitas airnya. Bak penampung, adalah bangunan bak kedap air untuk menampung air bersih dari mataair. Bak penampung mataair ditentukan berdasarkan debit minimum mataair, besarnya pemakaian dan waktu, asumsi kebutuhan 30 - 60 liter per orang per hari dan waktu pengambilan adalah 8 sampai 12 jam sehari. Pada bak penampung akan dibuat pipa masukan (inlet) dan keran keluar (outlet). Pipa inlet berfungsi sebagai unit masukan air ke bak penampung dan keran outlet berfungsi untuk mengeluarkan air dari bak penampung. Pembuatan manhole pada bak penampung juga akan dilakukan. Manhole tersebut berfungsi untuk pergantian udara, untuk jalan masuk manusia dalam rangka pemeliharaan dan perbaikan bak bagian dalam.

Perencanaan ukuran bak penampung harus disesuaikan dengan debit air pada mata air dan jumlah masyarakat yang akan menggunakan air tersebut. Luas bak penampung yang direncanakan mengacu pada Spesifikasi Teknis Perlindungan Mata Air (P MA) (AB-D/LW/ST/006/98), Departemen Pekerjaan Umum dalam Panduan Teknis Pengembangan SPAM Sederhana dapat dilihat pada tabel 10.

Debit mataair pada mataair sumberwatu dan marikangen dilokasi penelitian memiliki kesamaan yaitu <0,5 L/det. Apabila penggunaan air ditekan menjadi 30L per orang per hari sesuai asumsi maksimal yang digunakan untuk penentuan ukuran bak penampung, maka debit mataair dapat memenuhi kebutuhan air domestik 12 orang untuk mataair sumberwatu dan 55 orang untuk mataair marikangen. Berdasarkan kriteria bak penampung yang telah ditentukan, maka bak penampung yang direncanakan pada mata air sumberwatu dan mataair marikangen yaitu 5m3, dengan ukuran panjang $\mathrm{x}$ lebar $\mathrm{x}$ tinggi adalah $2,5 \mathrm{~m} \times 2 \mathrm{~m} \times 1 \mathrm{~m}$ atau samadengan $250 \mathrm{~cm} \times$ $200 \mathrm{~cm} \times 100 \mathrm{~cm}$. Tinggi bak penampung yang dipilih adalah 1m untuk memudahkan jangkauan atas bak penampung kaitannya dengan perawatan bak penampung secara rutin. Model bak penampung yang digunakan dapat dilihat pada Gambar 5.

Untuk mataair luwing tidak dilakukan pembuatan bak dikarenakan pada mataair tersebut debit yang dihasilkan tidak dapat memenuhi kebutuhan warga. Oleh karena itu konservasi yang dapat dilakukan untuk mataair luwing yaitu pembuatan pagar di sempanan mataair. Pagar keliling pada mataair dimaksudkan untuk melindungi mata air dari gangguan luar seperti manusia dan hewan. Garis pagar keliling ditentukan sejauh (5 - 10) m dari titik mata air dan tinggi pagar keliling ditentukan (1,8 2,2) m. Pada mataair dapat diletakkan atap untuk melindungi air dari kotoran hewan ataupun gangguan dari luar. Selain pada mataair luwing, pembuatan pagar keliling juga akan dilakukan untuk mataair sumberwatu dan mataair marikangen.

Pengolahan teknik pada daerah sempadan mataair ini tetap perlu adanya upaya pemeliharaan dan periksaan berkala oleh masyarakat. Pemeliharaan pada mata air agar terus beroperasi adalah sebagai berikut:

a. Perawatan rutin

- Bersihkan area sekitar mataair dari gangguangangguan luar;

- Bersihkan saluran pipa dan periksa bila ada kerusakan/kebocoran;

- Amati perubahan kualitas air yang terjadi terutama pada musim hujan. 
b. Pemeliharaan harian atau mingguan

- Bersihkan keran keluar dari tanah atau kotoran dan periksa kerusakan dan kebocoran, jika terjadi kerusakan cepat diganti;

- Pengecekan apabila ada sedimentasi material yang terbawa di dasar bak penampung air;

- Bersihkan kotoran sekitar bak penampung, cek bangunan dan perlengkapannya terhadap kerusakan. c. Pemeliharaan Bulanan dan Tahunan

- Periksa dan jaga sekitar radius 100 meter dari bangunan bak penampung dari pencemaran, kotoran dan kerusakan lingkungan;

- Bersihkan bak penampung dari lumut;

- Pengecekan pagar disekitar mataair dan bak penampung.

Tabel 10 Ukuran Bak Penampung (Spesifikasi Teknis Perlindungan Mata Air (P MA) (AB-D/LW/ST/006/98)

\begin{tabular}{|c|c|c|c|c|}
\hline \multirow{2}{*}{ Pelayanan Orang } & \multicolumn{4}{|c|}{ Debit } \\
\hline & $<0,5 \mathrm{~L} /$ detik & $0,5-0,6 \mathrm{~L} /$ detik & $0,7-0,8 \mathrm{~L} /$ detik & $>0,8 \mathrm{~L} /$ detik \\
\hline $200-300$ & $5 \mathrm{~m}^{3}$ & $2 \mathrm{~m}^{3}$ & $2 \mathrm{~m}^{3}$ & $2 \mathrm{~m}^{3}$ \\
\hline $300-400$ & $10 \mathrm{~m}^{3}$ & $5 \mathrm{~m}^{3}$ & $2 \mathrm{~m}^{3}$ & $2 \mathrm{~m}^{3}$ \\
\hline $400-500$ & $10 \mathrm{~m}^{3}$ & $10 \mathrm{~m}^{3}$ & $5 \mathrm{~m}^{3}$ & $\mathrm{~m}^{3}$ \\
\hline
\end{tabular}

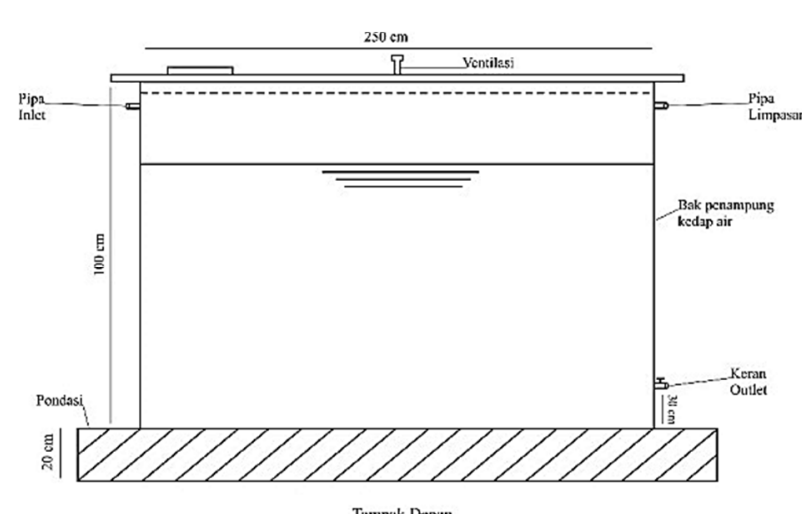

(a)

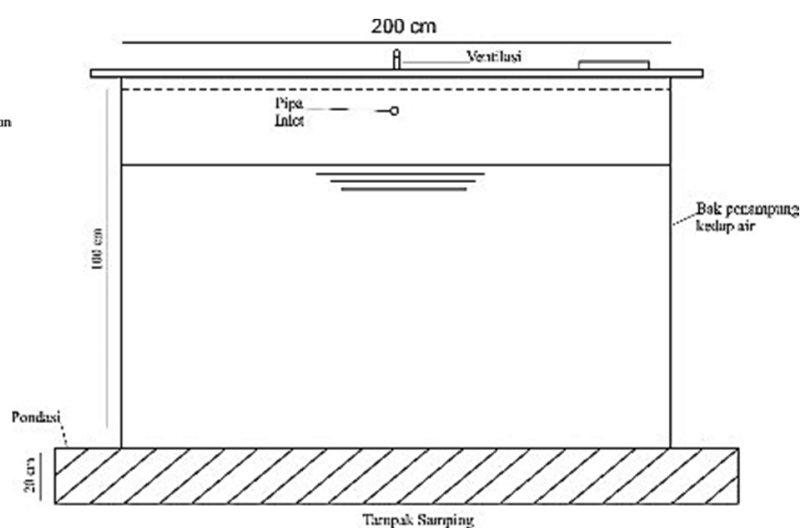

(b)

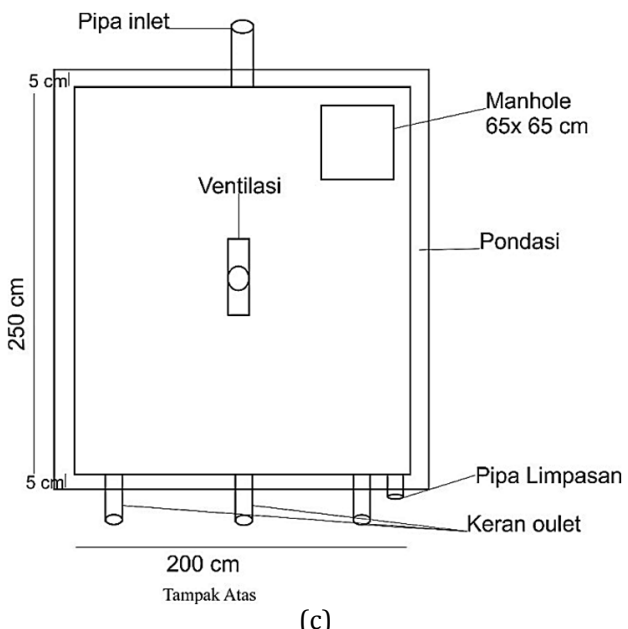

Gambar 5. Bak Penampung (a) Tampak Depan (b) Tampak Samping (c) Tampak atas Sumber : Desain Penulis,

\section{Kesimpulan}

Hasil penelitian Teknik Konservasi Mataair Dusun Sumberwatu dan Dusun Dawangsari, Desa Sambirejo, Kecamatan Prambanan, Kabupaten Sleman, Daerah Istimewa Yogyakarta, maka dapat disimpulkan sebagai berikut:

1. Berdasarkan terjadinya ketiga mataair memiliki tipe mataair turbuler dan berdasarkan sifat pengaliran termasuk mata air tahunan. Kuantitas (debit) 3 mataair tergolong kelas 7-8 dengan kualitas air pada seluruh mata air bakteri coliform tinggi dan parameter lain berada dibawah bakumutu.
2. Recharge area pada lokasi penelitian berada pada bagian timur dan bagian barat Dusun Sumberwatu dan Dusun Dawangsari

3. Arahan teknik konservasi yang dilakukan pembuatan saluran resapan dan rorak pada sistem teras gulud. Kemudian sistem mekanis di bak penampung mataair yakni alat Chlorine Diffuser untuk mengatasi bakteri coliform, serta teknik bangunan penangkap air dari sumber air (bak penampung). 


\section{DAFTAR PUSTAKA}

Arsyad, Sitanala, dan Rustiadi, E. (2012). Penyelamatan Tanah, Air, dan Lingkungan. Bogor: Crestpent Press

Badan Standarisasi Nasional (2005). Standar Nasional Indonesia Nomor SNI-03-7065-2005-plambing tentang tatacara perencanaan sistem plambing.

BPBD Kabupaten Sleman. (2015). Peta Risiko Bencana Kekeringan Kabupaten Sleman

Badan Pusat Statistik Yogyakarta. (2016). Kecamatan Prambanan Dalam Angka 2016

Departemen Pekerjaan Umum. (1998). Spesifikasi teknis perlindungan mata air (P MA) (ABD/LW/ST/006/98), Panduan Teknis Pengembangan SPAM Sederhana

Jocom, H., Kameo, D. D., Utami, I., dan Kristijanto, A. I. (2016). Air dan Konflik: Studi Kasus Kabupaten Timor Tengah Selatan. Jurnal Ilmu Lingkungan. 14(1),5161, doi:10.14710/jil.14.1.51-61

Kodoatie, dan Robert J. 2012. Tata Ruang Air Tanah. Yogyakarta: C.V Andi Offset

Kospa, H. S. D., dan Rahmadi. (2019). Pengaruh Perilaku Masyarakat Terhadap Kualitas Air Di Sungai Sekanak Kota Palembang Jurnal Ilmu Lingkungan, 17(2), 212221 doi:10.14710/jil.17.2.212-221

Meinzer, O. E. (1923), Outline of ground-water hidrology with definition, Geological Survei Water-Supplay Paper 494, United States Printing Office, Washington.

Peraturan Menteri Kesehatan RI No. 416 Tahun 1990 Tentang Syarat-syarat Dan Pengawasan Kualitas Air

Peraturan Menteri Pekerjaan Umum Dan Perumahan Rakyat Republik Indonesia No 14/PRT/M/2010 Tentang standar pelayanan minimal bidang pekerjaan umum dan penataan ruang.

Peraturan Menteri Pekerjaan Umum Dan Perumahan Rakyat Republik Indonesia No 28/PRT/M/2015 Tentang Penetapan Garis Sempadan Sungai dan Garis Sempadan Danau.

Peraturan Menteri Pekerjaan Umum Republik Indonesia No 02/PRT/M/2013 Tentang Pedoman Penyusunan Rencana Pengelolaan Sumber Daya Air.
Permana, A, P. (2019). Analisis Kedalaman dan Kualitas Air Tanah di Kecamatan Hulonthalangi Kota Gorontalo, Jurnal Ilmu Lingkungan 17(1),15-22, doi:10.14710/jil.17.1.15-22

Pohan, D. A. S., Budiyono, dan Syafrudin. (2016). Analisis Kualitas Air Sungai Guna Menentukan Peruntukan Ditinjau dari Aspek Lingkungan di Sungai Kupang Kota Pekalongan. Jurnal Ilmu Lingkungan,14(2),6371, doi:10.14710/jil.14.2.63-71

Riastika. M. (2011). Pengelolaan air tanah berbasis konservasi di recharge area boyolali, Jurnal Ilmu Lingkungan, Vol 9 (2): 86-97.

Sari, E. K., dan Wijaya, O. E. (2019). Penentuan Status Mutu Air dengan Metode Indeks Pencemaran dan Strategi Pengendalian Pencemaran Sungai Ogan Kabupaten Ogan Komering Ulu. Jurnal Ilmu Lingkungan, 17(3), 486-491, doi:10.14710/jil.17.3.486-491

Sudarmadji, Darmanto, D., Widyastuti, M., dan Lestari, S. 2016., Pengelolaan mata air untuk penyediaan air rumahtangga berkelanjutandi lereng selatan gunungapi merapi, Jurnal Manusia Dan Lingkungan, Vol. 23 (1): 102-110

Sudarmadji (2014). Pengelolaan Sumber Daya Air Terpadu. Yogyakarta: Gadjah Mada University Press

Sulistyorini, I. S., Edwin, M., dan Arung, A. S. 2016. Analisis kualitas air pada sumber mata air di kecamatan karangan dan kaliorang kabupaten kutai timur, Jurnal Hutan Tropis, Vol. 4 (1): 64-76 .

Taufik, I., Purwanto, M. Y. J., Pramudya, B., dan Saptomo, S. K. (2020). Alokasi air dan pengembangan prasarana penyediaan air baku di das ciliman. Jurnal Ilmu Lingkungan, 18(1),171-184, doi:10.14710/jil.18.1.171-184

Triatmodjo, B. (2009). Hidrologi Terapan. Yogyakarta: Beta Offset.

Yogafanny, E. (2015). Pengaruh aktifitas warga di sempadan sungai terhadap kualitas air sungai winongo, Jurnal Sains dan Teknologi Lingkungan, Vol 7 (1): 41-50. 